\title{
Supporting Technology 4.0: Ethoconstructivist Multimedia for Elementary Schools
}

\author{
https://doi.org/10.3991/ijoe.v15i14.11365 \\ Asrial, Syahrial ${ }^{\square}$, Dwi Agus Kurniawan, Rahmat Perdana, \\ Putut Nugroho \\ Universities Jambi, Jambi, Indonesia \\ syahrial.karea@gmail.com
}

\begin{abstract}
Education is a processor effort carried out by someone to gain knowledge, skills, and habits in life. Today education in Indonesia is much in fluenced by globalization and the development of technology, information, and communication (ICT). ICT has become one of the aspects that is very much considered in the world of education from now on. The use of ICT in planning, process, and evaluation of learning is a very lively discussion discussed by Indonesian education practitioners. The teacher must be able to process the development of ICT in a positive direction so that students do not forget their original culture as the Indonesian nation. many things teachers can do by using Tats in the learning process. Teachers can find more educational references, teachers can use ICT as a learning medium. By using e-learning, students will become more motivated in learning. One form of e-learning based learning is to use a 3D page flip book application. The e-book is an innovative book that is designed to produce printed books because it produces products in the form of soft and economical distribution files. The ethnic-constructivistic module developed here will use a professional 3D page flip. In this research, we will see how the implementation of e-learning-based learning, ethnoconstuctivist multimedia with module uses a 3D page flip book. In addition, in this study, it will also be seen how students' responses and motivation after learning using the 3D page flip book application.
\end{abstract}

Keywords-Technology 4.0; Multimedia; 3D page flip; Ethno constructivism

\section{Introduction}

Education is a processor effort carried out by someone to gain knowledge, skills, and habits in life. [1] Education is a very important activity, with the education of humans can change behavior and knowledge for the better. In Indonesia education is a matter that is always interesting to discuss. Starting from the education system, curriculum, facilities, teacher competencies, student delinquency, to global influences. [2] There are three main priorities: increasing equality and access, improving quality and relevance, and management approval and accountability. Today education in 
Indonesia is much influenced by globalization and the development of technology, information, and communication (ICT).

The current development of globalization requires education in Indonesia to be better and develop. [3] The concept of globalization, nation-states, and education are closely interrelated. As explained, globalization has now rethinked political and social structures, economic relations, and cultural values. ICT has now become one of the aspects that is considered and highlighted in the world of education. The use of ICT in planning, process, and evaluation of learning is a very lively discussion discussed by Indonesian education practitioners. [4] It is logical to say that the development of information and communication technology (ICT) affects all fields of education. The question is, have Indonesian education facilities been fulfilled? Have teachers as educators been able to apply ICT in learning? And there are still many other interesting issues to discuss.

Globalization forces the entry of outside culture into Indonesian society. This fears the loss of Indonesian native culture as a national identity. Here the teacher has a very vital role, where the teacher must be able to be a filter for the real culture that goes into students' thinking. The teacher must be able to process the development of ICT in a positive direction so that students do not forget their original culture as the Indonesian nation.

The skills of teachers in using ICT, especially elementary school teachers can be said to be still low. [5] Teachers of traditional teaching methods "dictation notes" have been shown to be remarkable in teaching and learning. This can be caused because the teacher does not understand about ICT, lack of training or because of the lack of available facilities [6] Technology adds value to education and supports more effective pedagogy by providing knowledge to students and improving communication that supports learning. In the development of globalization that is very heavy as currently teachers are required to master ICT well. Technology should have been applied in education in Indonesia.

One of the objectives of the application of ICT in education is to improve the quality and quantity of education and teachers in Indonesia. [7] ICTs make an acquisition of knowledge more accessible, and in the field of learning, involving students in the application of ICTs. Many things teachers can do by using Tats in the learning process. Teachers can find more educational references, teachers can use ICT as a learning medium. [8] This method gives itself confidence and motivation that increases learning. education and culture are two things that cannot be separated. Therefore, teachers must be able to teach students to use ICT without leaving the cultural values of students. Technology-based education or E-learning is one of the things that can be used by teachers in the learning process.

[9] E-learning and online courses refer to courses delivered partially or entirely online, synchronously or asynchronously. By using e-learning, students will become more motivated in learning. [10] Content that can be enjoyed more easily and whatever is available can use learning resources effectively or can activate the content themselves at home or school. In addition, e-learning will make it easier for teachers to deliver subject matter. One form of e-learning based learning is to use a 3D page flip book application. 
The e-book is an innovative book that is designed to produce printed books because it produces products in the form of soft and economical distribution files. [11]. The ethnic-constructivistic module developed here will use a professional 3D page flip.

In this research, we will see how the implementation of e-learning-based learning, ethnoconstuctivist multimedia uses a 3D page flip book. In addition, in this study, it will also be seen how students' responses and motivation after learning using the 3D page flip book application.

\section{Methodology}

This study uses a development and evaluation methodology. [12] The R \& D method is a research method used to produce certain products, and test the effectiveness of these products. The products produced from this research are in the form of 3D page flip ethno constructivist module teaching material that has been tested for its feasibility. The module development process here is to develop ethno constructivist modules in the form of a page flip 3D ebook using a professional 3D page flip application. The following is the step in creating an ethno constructivist 3D page flip module.

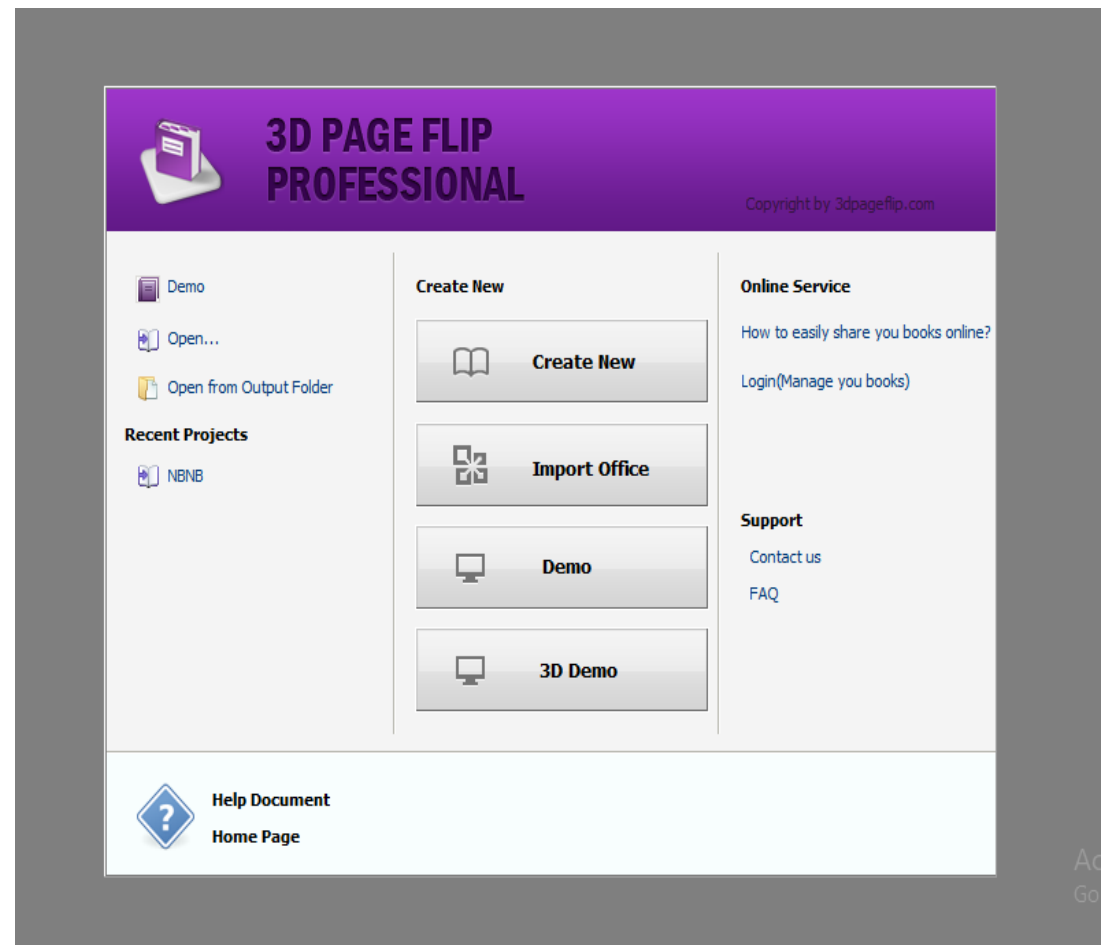

Fig. 1. The first step is to open a professional 3D page flip application, and it will reveal the display as above. Select "create now". 


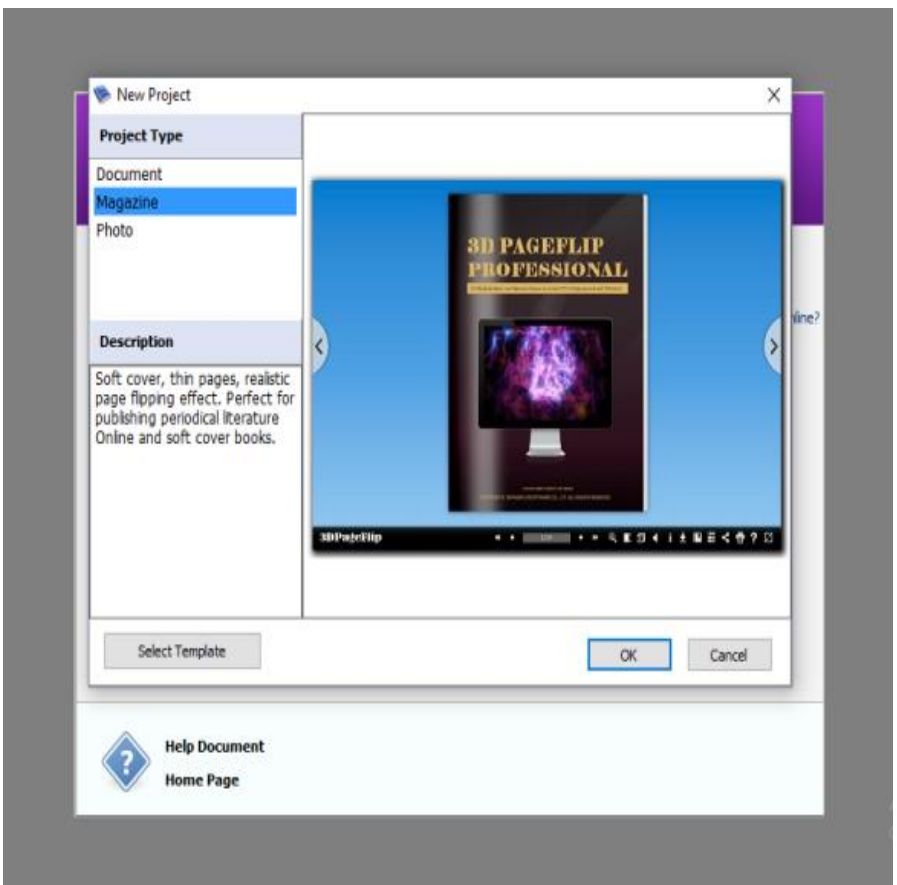

Fig. 2. After the following display appears select "magazine" and clicks "OK".

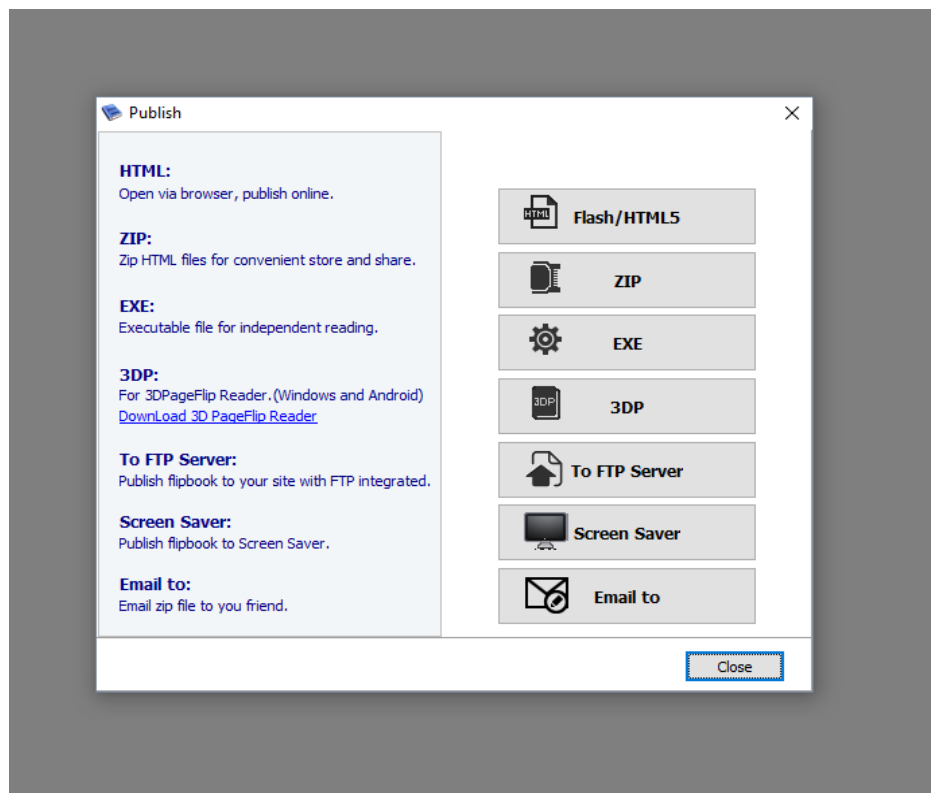

Fig. 3. Then the display will appear as shown above. Please select "3D" to make the module display into 3D page flip. 


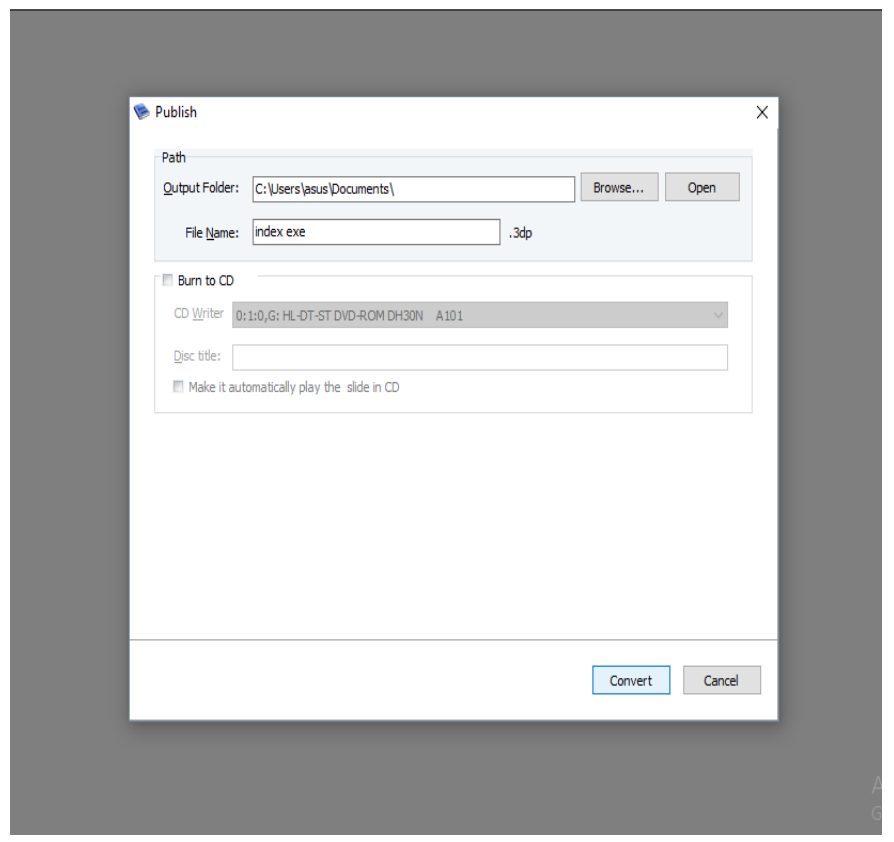

Fig. 4. After the following display appears, please select a place to save the file and file name. Then click "convert".

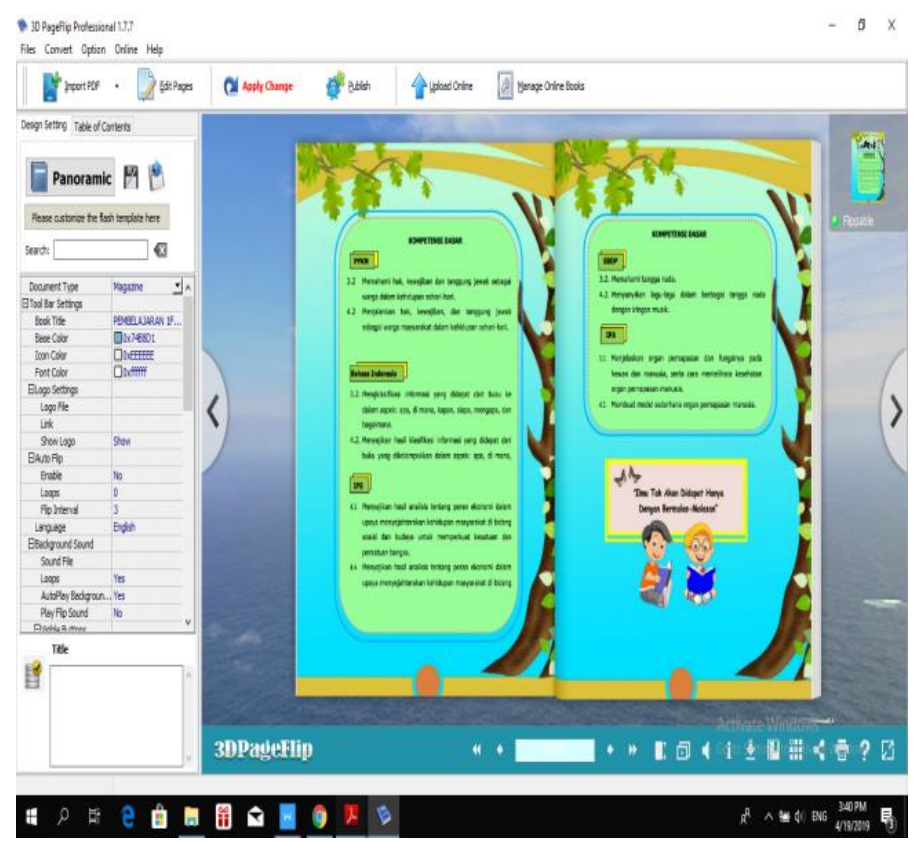

Fig. 5. The image above is a form of a $3 \mathrm{D}$ page flip display that has been created. 
Then after the completion, evaluation or trial will be carried out. [13] Evaluation was carried out with a series of empirical tests involving users (students and teachers) of the models that had been developed. The trial conducted in this study was a small group trial, which will be conducted on elementary school students.

The sample from this study was grade V elementary school students in three districts in Jambi Province with 156 students. In addition to the students, the researchers also took fifth-grade teachers from elementary schools from three districts in Jambi Province with 12 teachers. The flow of this research is to develop ethnoconstivism modules with professional 3D page flip models. Then the researchers conducted a trial at the elementary school. After the trial is done, the researcher will see the response of students and teachers. Students and teacher responses will be seen using a response questionnaire that will be shared with students and teachers. Questionnaire data that has been obtained, will be analyzed using SPSS 22 Software and will be displayed in table 1 . The categorization of the questionnaire value results is as follows:

Table 1. Category questionnaire for Students and Teacher

\begin{tabular}{|c|l|}
\hline Value Range & \\
\hline $20.0-36.0$ & Category \\
\hline $36,1-52,1$ & Not Good \\
\hline $52,2-68,2$ & Enough \\
\hline $68,3-84,3$ & Good \\
\hline $84,4-100,4$ & Very Good \\
\hline
\end{tabular}

In addition to the questionnaire, interviews were also conducted to obtain more indepth data on student and teacher responses. The results of student and teacher interviews, will then be analyzed using data analysis techniques by Miles and Huberman.

\section{Results and Discussion}

The module created is a learning module by incorporating cultural values that are around students. Integration of local cultural values in the module is so that students more easily understand learning material. The making of this module uses a constructivist learning approach, so this module is called an ethno constructivist module. [14] The constructivist learning processes support students' active participation, knowledge construction, and deep learning, encourage students to think and act independently, and foster permanent learning.

The ethnic-constructivism module is a module that contains learning material where the material is seen in terms of culture. This ethnic-constructivism module is then developed using a professional 3D page flip application. The development of ethnic-constructivism modules into professional 3D page flip applications is a form of e-learning development so students are more interested in learning. 


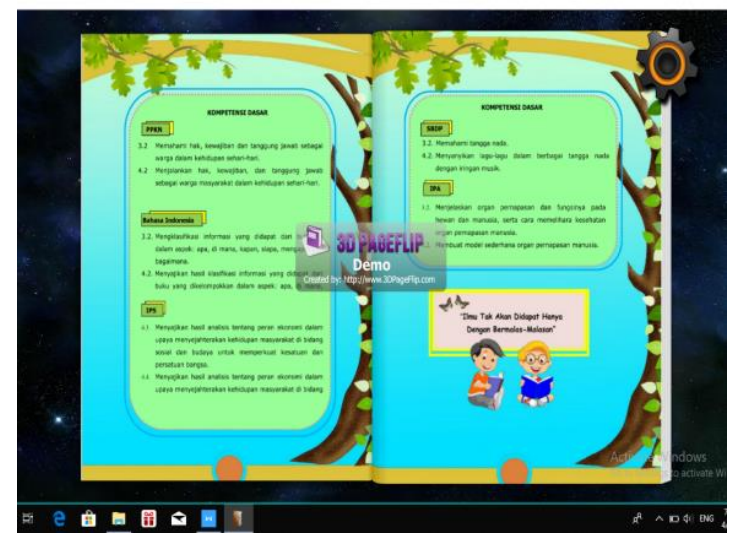

Fig. 6. View the 3D page flip ethnic-constructivism module

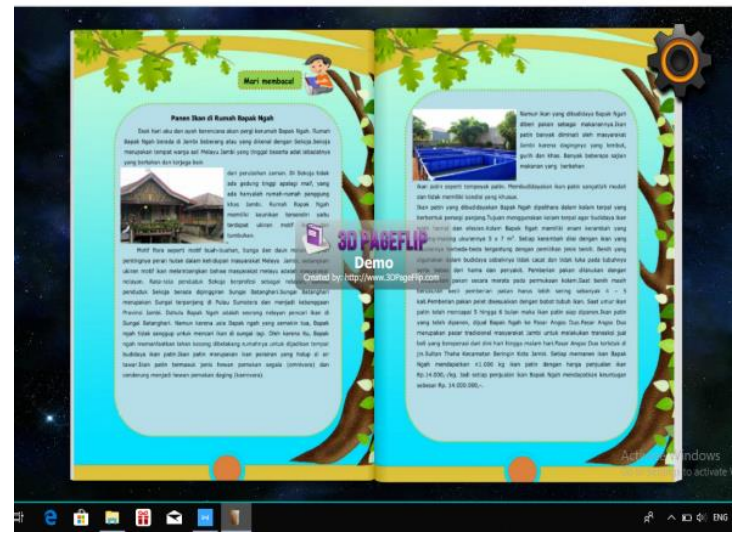

Fig. 7. Display the 3D page flip ethnic-constructivism module

After the development of the ethno constuctivistic module using 3D page flip was completed, a demonstration was held to elementary school students.

From the demonstration activities, the data obtained from the responses of students and teachers were as follows:

Table 2. . Results of student responses

\begin{tabular}{|l|c|c|}
\hline \multicolumn{1}{|c|}{ Category } & Frequensi & \% \\
\hline Not Good & 0 & 0 \\
\hline Less Good & 0 & 0 \\
\hline Enough & 65 & 41,7 \\
\hline Well & 90 & 57,7 \\
\hline Very Good & 1 & 6 \\
\hline Total & 156 & 100.0 \\
\hline
\end{tabular}


From the table shows that students' responses to the page flip ethno constructivist $3 \mathrm{D}$ module tend to be good. If this is seen from the percentage, as many as $57.7 \%$ of students' responses to the ethno constructivist 3D page flip module fall into the Good category.

Next is the teacher's response to the ethno constructivist 3D page flip module. The results of the response data were obtained by giving a questionnaire response to 12 grade $\mathrm{V}$ teachers in elementary school. The results are as follows:

Table 3. Results of teacher responses

\begin{tabular}{|l|c|c|}
\hline \multicolumn{1}{|c|}{ Category } & Frequensi & \% \\
\hline Not Good & 0 & 0 \\
\hline Less Good & 1 & 8 \\
\hline Enough & 5 & 42 \\
\hline Well & 6 & 50 \\
\hline Very Good & 0 & 0 \\
\hline Total & 12 & 100 \\
\hline
\end{tabular}

Based on the results of calculations in the table, the results showed that the teacher's response tended to be good with a percentage of $50 \%$, while the response was given by 5 teachers or $42 \%$, and the rest showed a poor response.

In addition to the response data using questionnaires, student and teacher responses were also seen based on the results of the interview. The following is the result of interviews with students regarding students' responses to the ethno constructivistic 3D page flip module.

"We are very happy to learn to use a 3D page flip module because the display of the module is very interesting" (student interview, April 18, 2019).

"I like learning with computers, I have never been invited to learn to use computers before. The lessons are also easy"(student interview, 18 April 2019).

"Learning is fun, I and my friends like to learn to use a laptop. It's just that there is no laptop at home, so it's hard to study at home "(student interview, 19 April 2019).

Students tend to give a good response when asked about ethno constructivist 3D page flip modules. Students are very enthusiastic and very interested in using technology in learning activities. But students also complained about the facilities they have and the limited ability to operate a laptop. In addition to conducting interviews with students, interviews were also conducted with the teacher. The purpose of the teacher interview is the same as the purpose of the interview with students, namely to see the teacher's response to the ethno constructivist 3D page flip module. The results of teacher interviews are as follows:

"The module is very good, it helps a lot in learning, because as we see students are very happy. Students really enjoy learning to use the laptop or the 3D page flip module. If all the modules are like this, I am sure the child's motivation to learn will definitely increase" (teacher interview, 18 April 2019).

"The module is good, the contents are good, it matches the Core Competencies and Basic Competencies. The module is also good because it elevates the local culture of 
the surrounding community so children are easier to understand the material ". (teacher interview, 18 April 2019).

"This module is good, kids like it. But we old teachers don't understand how to use it, so it's difficult for us to be able to use that as well. Wearing it is difficult especially we have to be told to make it. Modules that are like that are not required in the curriculum. (teacher interview, April 19, 2019).

Seeing teacher responses to page flip ethno constructivist 3D modules tends to be good. Modules are considered to be in line with core competencies and basic competencies. But some teachers say that page flip-based 3D modules are very difficult for them. One of these factors is the age of the teacher. Because the teacher thought that to apply the 3D ethno constructivist module page flip was very difficult, and the teacher was also unable to make the module.

Based on what has been described, we can know that the student response is very positive towards the 3Dpageflip ethno constrictive module. [15] This has made many educators mobilize efforts to help students get interactive content full of multimedia because it has been proven that it has a significant influence on the learning process. using eBook 3D page flip will make learning more fun and more efficient. Students can learn about the culture and the surrounding environment using the 3D page flip ethnic-constructivism module. The page flip 3D ethnic-constructivist module can also be used on Android or Smartphone systems using the 3D page flip reader application. [16] Multimedia is a module that is published and stored in a digital version of a computer using a word processor and can be accessed by users via the internet. This will make it easier for students to be able to study at home with their parents.

When viewed from the results of interviews, students are very happy and more motivated to learn to use the 3D page flip ethnic-constructivism module. Students prefer learning to use laptops and other technological tools. It's just that students still can't use or operate a laptop as a learning medium. In addition, the availability of computers or commercial laboratories in elementary schools is still very minimal, so that facilities become obstacles to the use of information and communication technology (ICT).

Meanwhile, to see the teacher's response, the responses were used and interviews were also used. The day the results of the questionnaire were obtained, it was seen that the teacher's response tended to be good with a percentage of $50 \%$, and as many as $42 \%$ of the teacher's responses in the category were sufficient. Interestingly, one teacher stated that the response was unfavorable to the ethno constructivist 3D page flip module. [17] Revolution in the field of information and communication technology (ICT), is a major challenge for the development of teacher professional competencies. They must learn adequate ICT skills to use productively, as well as to teach and guide students to use ICT in a generative and purposeful manner.

Based on the results of the interview, the teacher who stated that the response was not good stated that as an old teacher, the teacher had difficulty to operate the computer. In addition, the teacher's ability to make ethno constructivist modules is still very limited, plus school facilities that have not facilitated computer laboratories. [18] This lack of trust in their subject knowledge compared to their ICT knowledge and 
skills. The rest of the teacher's response showed a good response about the ethno constructivist 3D page flip module.

Assessment is considered important because competency requires an evaluation method that is tailored to its nature, that is, assessment activities and learning activities must be of the same type [19]. The use of information and communication technology can provide updates in the world of education in this case e-module. The use of innovative ICT-based applications can be used in learning [20]. In addition, students are motivated to learn in class because the classroom is comfortable and makes students eager to go to school [21]; [24]. Because a comfortable classroom can foster students' interest and pleasure in learning [22]. Then when the lesson takes place, students look happy when the teacher uses the e-module to work on the questions or physics assignments given by the teacher. Because students have an inner spirit that causes stimulation to do anything. Students who have the willingness to learn are generated from within themselves [23].

\section{Conclusion}

From the results and discussion that has been described, it can be concluded that by using the ethno constructivist 3D page flip module, the responses of students and elementary school teachers tend to be good. Students are more motivated in learning to use the ethno constructivist 3D page flip module. Students more easily understand the material about local and surrounding cultures using the 3D page flip module. It's just that students and teachers find the same constraints, namely the lack of skills in the application of technology and the availability of facilities and infrastructure.

Learning based modules are indeed very good and can motivate students to learn more. Therefore, teachers should be more creative to develop and create interesting modules or teaching materials, especially e-learning-based teaching materials such as 3D page flip.

\section{Acknowledgement}

The researcher would like to thank the Principals, Teachers, and students, as well as all those who have been related during the making of this article, I would like to thank you.

\section{References}

[1] Astalini., Kurniawan, D. A., Perdana, R., \& Kurniasari, D. (2018). "Identification of Student Attitudes toward Physics Learning at Batanghari District High School”. The Educational Review, USA, 2(9), 475-484. https://doi.org/10.26855/er.2018.09.003

[2] Firman, H \& Tola, B. (2008) "The Future of Schooling in Indonesia” Journal of International Cooperation in Education, Vol.11, No.1, pp.71-84. 
[3] Parjanadze, N. (2009). "Globalisation Theories and Their Effect on Education" IBSU Scientific Journal, 2(3), pp. 77-88.

[4] Al-Munawwarah, S. F. (2014). "Teachers' perceptions on the use of ICT in Indonesian EFL learning context”. English Review: Journal of English Education. Vol 3. No 1, pp. 7080 .

[5] Jadhav, V. (2011). "ICT and Teacher Education" International Educational E-Journal, vol 1, no 1, pp. 64-69.

[6] Bakar, R. \& Mohamed, S. "Teaching using information and communication technology: Do trainee teachers have the confidence?" International Journal of Education and Development using Information and Communication Technology (IJEDICT), vol, 4, no, 1, pp. 512, 2008.

[7] Fu, J.S. (2013). "ICT in Education: A Critical Literature Review and Its Implications" International Journal of Education and Development using Information and Communication Technology (IJEDICT), vol. 9, no 1, pp. 112-125.

[8] Bansal, D. (2016). "Benefits of Ict In Education" Bhartiyam International Journal Of Education \& Research. Vol 5, No 2.

[9] Lister, M. (2014). "Trends in the Design of E-Learning and Online Learning" MERLOT Journal of Online Learning and Teaching. Vol. 10, No. 4,

[10] Kaewkiriya, T. (2013). "A DESIGN AND DEVELOPMENT OF E LEARNING CONTENT FOR MULTIMEDIA TECHNOLOGY USING MULTIMEDIA GAME” International Journal of Software Engineering \& Applications (IJSEA), Vol.4, No.6. https://doi.org/10.5121/ijsea.2013.4606

[11] Raihan, S. Haryono. \& Rahmadi, F. (2018). "E-Book Development, Scientific Learning Using the 3D Professional Pageflip Program" Innovative Journal of Curriculum and Educational Technology. Vol 7. No 1. pp. 7-14.

[12] Sugiyono. 2013. Metode Penelitian Kuantitatif, Kualitatif dan R\&D. Bandung: Alfabeta.

[13] Sahidu, A. et.al. (2017). "DESAIN SISTEM E-ASSESSMENT PADA PEMBELAJARAN FISIKA DI LPTK” Jurnal Pendidikan Fisika dan Teknologi. Vol 3. No 2. https://doi.org/10 $.29303 /$ jpft.v3i2.422

[14] Colak, E. (2017). "Teachers' Experiences in a Professional Learning Community on The Constructivist Lesson Planning: A Case Study Among Primary School Teachers". Education and Science.Vol 42. No 190. https://doi.org/10.15390/EB.2017.6911

[15] El-Seoud, M.S.A. (2014). "E-Learning and Students' Motivation: A Research Study on the Effect of E-Learning on Higher Education”. iJET. Vol 9, No 4, https://doi.org/10.3991/ ijet.v9i4.3465

[16] Ratheeswari, K. (2018). "Information Communication Technology in Education".Journal of Applied and Advanced Research. Vol 3. No 1. pp. 45-47. https://doi.org/10.21839/ jaar.2018.v3iS1.169

[17] Hakkareinen, K. et.al. (2001). "Teachersí Information and Communication Technology (ICT) Skills and Practices of Using ICT and Their Pedagogical Thinking”. Journal of Technology and Teacher Education. Vol 9. No 2. pp.181-197.

[18] Morley., G. (2011). "Primary Teachers, and ICT: Is gender, age or experience important?". SYSTEMICS, CYBERNETICS, AND INFORMATICS. Vol 9. No 7.

[19] Xing, Lifu. (2018). Evaluation of Physical Education Multimedia Teaching for Data Assimilation. International Journal of Online and Biomedical Engineering. 14(4). 30-42. https://doi.org/10.3991/ijoe.v14i04.8366

[20] Romero, S., Guenaga, M., Garcia-Zubia, J., \& Orduna, P. (2015). Automatic Assessment of Progress Using Remote Laboratories. International Journal of Online and Biomedical Engineering. 11(2), 49-54. https://doi.org/10.3991/ijoe.v11i2.4379 
[21] Karyotaki, M., \& Drigas, (2015). A. Online and other ICT Applications for Cognitive Training and Assessment. International Journal of Online and Biomedical Engineering. 11(2), 36-42. https://doi.org/10.3991/ijoe.v11i2.4360

[22] Bhukuvhani, C., Kusure, L., Munodawafa, V., Sana, A., \& Gwizangwe, I. (2010). Pre-service Teachers' Use of Improvised and Virtual Laboratory Experimentation in Science Teaching. International Journal of Education and Development using Information and Communication Technology, 6(4), : 27-38.

[23] Sorensen, E. (2013). Implementation and student perceptions of e-assessment in a Chemical Engineering Module. European Journal of Engineering Education, 38(2), 172-185. https://doi.org/10.1080/03043797.2012.760533

[24] Astalini., Kurniawan, D. A., Sulistyo, U., Perdana, R., \& Susbiyanto. (2019). EAssessment Motivation in Physics Subjects for Senior High School. International Journal of Online and Biomedical Engineering. 15(11), 4-15.

\section{$7 \quad$ Authors}

Asrial is professor in the study of indigenous knowledge chemical field. This knowledge can be applied to 21 st Century learning at the elementary, junior and senior high school levels. And preparing teacher candidates to understand the value of local wisdom to improve competence pedagogical. By applying education based on local wisdom it is hoped that it will be able to create education that gives meaning in the learning process for students. So that education is able to create young generations who are able to preserve and love their own culture. In addition, education must be able to shape human character with high integrity and great character and dignity in accordance with the spirit of education which is humanizing humans. Asrial is the chair of the research group ethno constructivism and that group is aimed at analyzing all the values of local wisdom to serve as a medium and source of learning.

Syahrial is an associate professor in the study of indigenous knowledge language and linguistic field. Language as a cultural product of local wisdom is one of the markers of civilization. Ethnic language (local) has an important function and role as important as the national language and international language as a bridge in global communication. Decreasing the vitality of ancestral languages will affect the safeguarding of local wisdom values. Noble advice contained in culture will stop being inherited as language skills fade. So from that, the value of local wisdom must be maintained, explored and developed for students. This is intended so that later the development of culture and science becomes the basis for human resource development. Syahrial is a member of the research group ethno constructivism and works at the Elementary Teaching and Education Program, Universities Jambi. Email id: syahrial.karea@gmail.com

Dwi Agus Kurniawan is a lecturer and member of the ASPS Group Research (Attitude towards Science and Science Processing Skills). His research interest includes E-Assessment and Evaluation specially in Attitude Towards Physics and Science Processing Skills. The age level of a child will experience very much difference, both in the form of his mindset, his skills, his relationships, and his attitude as a student. For teachers, it is very useful to know the differences in the mindset of their students, 
and about their daily interactions, and the behavior of their students. Benefits that can be obtained are: can create the right classroom for students, can provide innovative and varied learning methods, can provide lessons on deep moral aqidah, and explain the consequences for those who violate certain rules. He works at Science Education Program, Universitas Jambi Indonesia.

Rahmat Perdana is a graduate student in and member Group Research ASPS (Attitude towards Physics and Science Processing Skills). Science Education Program, Universitas Jambi, Jalan Raya Jambi - Ma. Bulian, KM 15, Mendalo Indah, Jambi, 36361, Indonesia. His research interest include E-Assessment and Evaluation specially in Attitude towards Physics and Science Processing Skills Email id: rahmat260997 @gmail.com

Putut Nugroho is a graduate student at universitas Jambi and member of the research group ethno constructivism and that group is aimed at analyzing all the values of local wisdom to serve as a medium and source of learning.

Article submitted 2019-07-17. Resubmitted 2019-08-30. Final acceptance 2019-09-02. Final version published as submitted by the authors. 